http://www.jrdms.dentaiau.ac.ir
JRDMS Journal of Research in Dental and Maxillofacial Sciences
$\mathrm{p}(\mathrm{ISSN}): 2588-4166$

\title{
Effect of Disinfection on the Surface Roughness of Dental Casts Retrieved from Addition Silicone Impressions
}

\author{
Mostafavi $\mathbf{A}^{\mathbf{1}}$, Koosha $\mathbf{S}^{2 *}$, Amjad $\mathbf{M}^{3}$ \\ ${ }^{1}$ Assistant Professor, Prosthodontics Dept, School of Dentistry, Tehran University of Medical Sciences, Tehran, Iran \\ ${ }^{2}$ Assistant Professor, Fixed Prosthodontics Dept, Member of implant research center, Dental Branch of Tehran, Islamic Azad University, Tehran, Iran. \\ ${ }^{3}$ Dentist
}

\begin{tabular}{l}
\hline ARTICLE INFO \\
\hline Article Type \\
Original Article \\
\hline Article History \\
Received: Nov 2017 \\
Accepted: Dec 2017 \\
ePublished: Jan 2018
\end{tabular}

Keywords:

Disinfectants,

Dental Gypsum,

Silicone Impression

Material,

Surface Properties

\begin{abstract}
Background and aim: Changes in the physical properties of casts retrieved from disinfected impressions are a common problem in the fabrication of dental prostheses. However, there are limited data available about the effect of disinfecting solutions on the surface roughness of casts. This study aimed to assess the surface roughness of casts retrieved from addition silicone impressions disinfected by immersion in three different disinfectants for 5 and 30 minutes.

Materials and methods: This in-vitro experimental study was conducted on 49 casts in 7 groups $(n=7)$. A standard stainless steel die was used according to ANSI/ADA specification no. 25 , and impressions were made using a low-viscosity addition silicone impression material. The impressions were disinfected by immersion in $1 \%$ sodium hypochlorite $(\mathrm{NaOCl}), 2.4 \%$ glutaraldehyde, or $5 \%$ povidone-iodine for 5 and 30 minutes. All impressions were poured with type IV dental stone, and their surface roughness $(\mathrm{Ra})$ was measured using a digital hand-held roughness tester. Data were analyzed using two-way analysis of variance (ANOVA) and Tukey's test.

Results: One-way ANOVA showed a statistically significant difference between the control group and the other 6 groups $(\mathrm{P}=0.004) .1 \% \mathrm{NaOCl} / 5$ minutes was the only group which presented a different result from the control group $(\mathrm{P}=0.012)$. Two-way ANOVA showed that over time, the surface roughness of casts retrieved from silicone impressions disinfected by immersion in a disinfectant decreased $(\mathrm{P}=0.002)$, but no significant difference was noted between the disinfectant agents $(\mathrm{P}=0.243)$.

Conclusion: The type of the disinfectant had no significant effect on surface roughness, although an increased duration of disinfection decreased the surface roughness of casts.
\end{abstract}

Please cite this paper as: Mostafavi A, Koosha S, Amjad M. Effect of Disinfection on the Surface Roughness of Dental Casts Retrieved from Addition Silicone ImpressionsJ Res Dent maxillofac Sci. 2018; 3(1):27-33. 


\section{Introduction:}

Changes in the physical properties of casts retrieved from impressions disinfected with different agents is a common problem causing prosthetic misfit in the oral cavity and on the casts. ${ }^{(1-3)}$ Impression materials are in contact with blood and saliva and can transmit infectious microorganisms to dental casts. $(4,5)$ The standard protocol is to rinse the impression under running water to eliminate microorganisms. ${ }^{(5)}$ Hepatitis B virus (HBV), human immunodeficiency virus (HIV), and Mycobacterium tuberculosis (TB) are among the microorganisms that can be transmitted and compromise the health of dentists, technicians, and assistants. ${ }^{(6,7)}$ At present, impressions are disinfected in clinics and laboratories aiming to eliminate microorganisms from the impression surface. ${ }^{(8-10)}$

One of the side effects of disinfection is the dimensional change of the impression due to chemical or physicochemical reactions between the disinfecting agent and the impression material. ${ }^{(1-3)}$ According to the World Dental Federation (FDI) protocol in 1998, all impressions should be disinfected before sending to the laboratory. ${ }^{(11)}$ Disinfection of impressions by spray is a common technique, but the immersion of an impression in a disinfecting solution is a more suitable and widely accepted method for disinfection. ${ }^{(11)}$ Disinfecting solutions commonly used in dentistry include sodium hypochlorite $(\mathrm{NaOCl})$, glutaraldehyde, iodophor, and phenol. However, none of the disinfecting solutions is perfectly compatible with impression materials and may cause changes in their dimensional stability. ${ }^{(1-3,12,13)}$ Moreover, working cast and die systems made of gypsum and dental stone must have dimensional stability, strength, and wear resistance, and should well reproduce the surface details.

It is believed that immersion of impressions in disinfectants for longer than the time recommended by the manufacturer can cause changes in the impression material, which can be transferred to the cast. ${ }^{(3,14-16)}$ Increasing the immersion time of an impression material in disinfectants would change the properties of gypsum casts, including surface detail reproduction, dimensional stability, and hardness, which will affect the accuracy of final restorations.

Most of the previous studies are focused on these characteristics, while very few studies have evaluated the effect of disinfectants on the surface roughness of dental casts. ${ }^{(9,16)}$ Therefore, this study aimed to assess and compare the surface roughness of casts retrieved from addition silicone impressions disinfected with $1 \% \mathrm{NaOCl}$, $2.4 \%$ glutaraldehyde, and 5\% povidone-iodine by immersion for 5 and 30 minutes. The null hypothesis was that the type of the disinfectant and the immersion time would have no significant effect on the surface roughness of casts.

\section{Materials and Methods:}

This in-vitro experimental study was conducted on 49 casts in 7 groups $(n=7)$. A master model of a stainless steel die ( $30 \mathrm{~mm}$ diameter $\times 15 \mathrm{~mm}$ height) according to ANSI/ADA specification no. $25^{(15)}$ was used in this study (Figure 1).

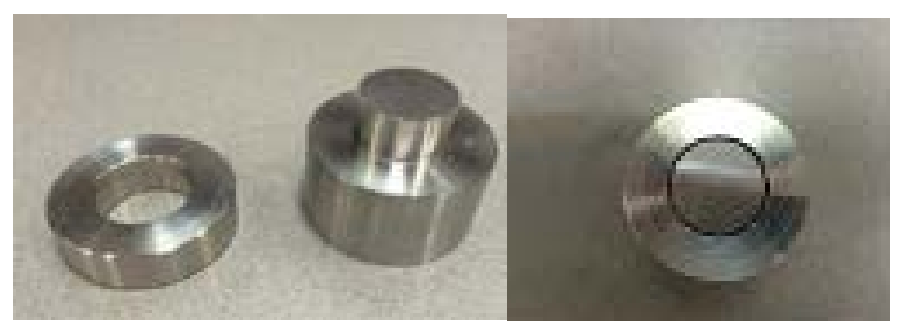

Figure 1. Stainless steel die and impression mold.

There was an appendage at the peripheral part of the impression mold in order to make a unique path of insertion of the stainless steel die into the mold. Panasil ${ }^{\circledR}$ Adhesive (Kettenbach Dental Co., Germany) was applied for 10 minutes to the internal surface of the impression mold before impression taking. A low viscosity addition silicone (Panasil ${ }^{\circledR}$; Kettenbach Dental Co., Germany) was prepared according to the manufacturer's instruction (Table 1). After applying the impression material to the impression mold, a plastic sheet was placed over the material to 
Table 1. Properties of the impression material and the gypsum

\begin{tabular}{llllll} 
Name & Manufacturer & Type & Mixing Time & Setting Time & Powder/Liquid Ratio \\
\hline Panasil ${ }^{\circledR}$ & $\begin{array}{l}\text { Kettenbach Dental Co., } \\
\text { Germany }\end{array}$ & $\begin{array}{l}\text { Light Body Addition } \\
\text { Silicone }\end{array}$ & 1 minute $<$ & $>2.5$ minutes & ----- \\
\hline Snow Rock & $\begin{array}{l}\text { Mungyo, } \\
\text { Korea }\end{array}$ & Vel-Mix Type IV & $\begin{array}{l}30-60 \text { seconds } \\
\text { (manual) } \\
20-30 \text { seconds } \\
\text { (vacuum) }\end{array}$ & 2 hours & $20 \mathrm{ml} / 100 \mathrm{~g}$ \\
& & & & \\
\hline
\end{tabular}

ensure a precise contact of the impression material with the die. This arrangement provided a 1-mm space for the impression material. Also, a 1-kg weight was placed over the mold in order to simulate the operator's finger pressure. This complex was then transferred to a water bath at $35^{\circ} \mathrm{C}$ to simulate the oral environment. ${ }^{(15)}$ After setting of the impression material, the complex was removed from the water, and the metal mold containing the impression was separated from the metal die. In each group, the impressions were immersed in a disinfecting solution for 5 or 30 minutes at room temperature, followed by rinsing with cold water for 10 seconds and drying. ${ }^{(15,17,18)}$

In the control group, the impressions were rinsed with sterile water without disinfection. The study groups were as follows:

I: The control group was subjected to no disinfecting solution.

II: Impressions were immersed in $1 \% \mathrm{NaOCl}$ (Clorox ${ }^{\circledR}, \mathrm{CA}, \mathrm{USA}$ ) for 30 minutes.

III: Impressions were immersed in $2.4 \%$ glutaraldehyde (Behsadex, Behsa Pharmaceutical Co., Arak, Iran) for 30 minutes.

IV: Impressions were immersed in 5\% povidone-iodine (Behsadine, Behsa Pharmaceutical Co., Arak, Iran) for 30 minutes.

$\mathrm{V}$ : Impressions were immersed in $1 \% \mathrm{NaOCl}$ for 5 minutes.

VI: Impressions were immersed in $2.4 \%$ glutaraldehyde for 5 minutes.

VII: Impressions were immersed in 5\% povidone-iodine for 5 minutes.
The properties of the disinfecting solutions used in this study are presented in Table 2. All impressions were poured with gypsum type IV (100 g of gypsum plus 19-24 ml of water; Snow Rock, Mungyo, Korea; Table 1) after one hour, and the casts were separated from the impressions two hours later ${ }^{(15)}$ (Figure 2).

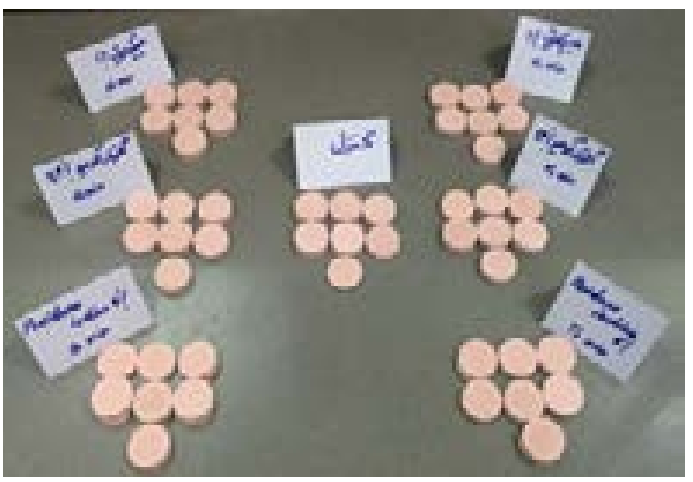

Figure 2. Casts coded in seven groups

The surface roughness ( $\mathrm{Ra})$ of the casts was measured using a digital hand-held roughness tester (TR200-TIME Group Inc., CA, USA). Three random points were selected on each specimen's surface, and the surface roughness of each point was measured separately. The mean of the three surface roughness values was calculated and reported as the specimen's Ra parameter. Data were analyzed with one-way analysis of variance (ANOVA). The homogeneity of variances and the normal distribution of data were verified by Kolmogorov-Smirnov test. Since a significant difference was reported between the control group and the other 6 groups $(\mathrm{P}=0.004)$, data were analyzed using two-way ANOVA and Tukey's test in SPSS 22 statistical software (IBM Co., Chicago, IL, USA) in order to compare the groups $(\alpha=5 \%)$. 


\section{Results}

One-way ANOVA showed a statistically significant difference between the control group and the other 6 groups ( $\mathrm{P}=0.004$; Table 3 and Figure 3$)$.

\begin{tabular}{lclll} 
Group & Mean \pm SD $(\boldsymbol{\mu m})$ & Minimum & Maximum & P-value \\
\hline I. Control group & $0.867 \pm 0.054$ & 0.804 & 0.934 & \\
\hline II. 1\% NaOCl/30 minutes & $0.817 \pm 0.077$ & 0.736 & 0.927 & P $\leq \mathbf{0 . 0 5}$ \\
\hline III. 2.4\% glutaraldehyde/30 minutes & $0.840 \pm 0.097$ & 0.710 & 1.024 & \\
\hline IV. 5\% povidone-iodine/30 minutes & $0.893 \pm 0.183$ & 0.698 & 1.269 & \\
\hline V. 1\% NaOCI/5 minutes & $1.048 \pm 0.146$ & 0.827 & 1.246 & \\
\hline VI. 2.4\% glutaraldehyde/5 minutes & $0.893 \pm 0.047$ & 0.807 & 0.941 & \\
\hline VII. 5\% povidone-iodine/5 minutes & $0.957 \pm 0.040$ & 0.898 & 1.003 & \\
\hline
\end{tabular}

$\mathrm{NaOCl}=$ Sodium hypochlorite, $\mathrm{SD}=$ Standard Deviation

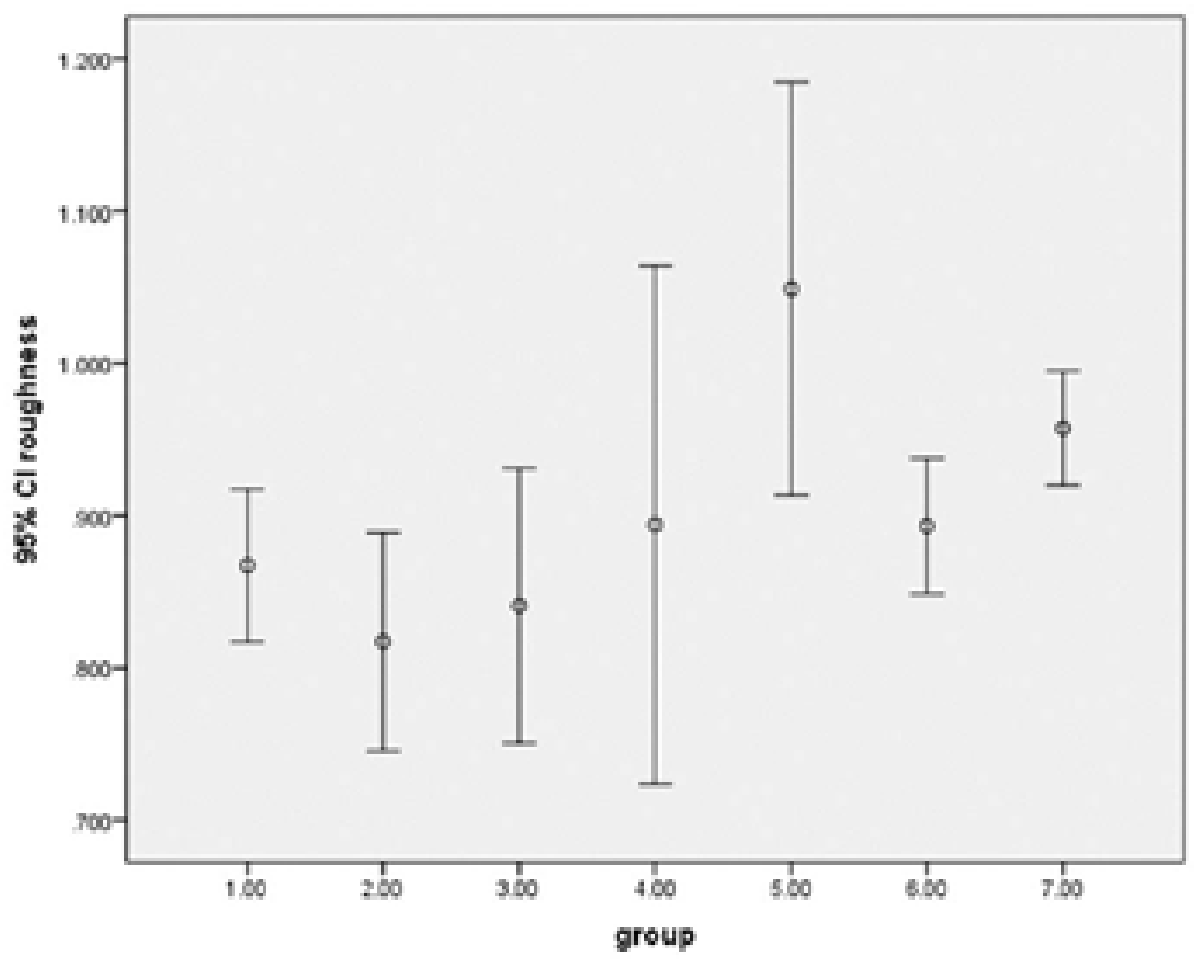

Figure 3. Normal distribution of data 
$1 \% \mathrm{NaOCl} / 5$ minutes was the only group which presented a different result from the control group $(\mathrm{P}=0.012$; Table 4$)$.

Table 4. Results of Dunnett's test regarding the differences between the case and control groups

\begin{tabular}{llll}
\hline Group & $\begin{array}{l}\text { Mean } \\
\text { difference }\end{array}$ & $\begin{array}{l}\text { Std. } \\
\text { Error }\end{array}$ & $\begin{array}{l}\text { P- } \\
\text { value }\end{array}$ \\
\hline NaOCl/30 minutes & -0.050 & 0.056 & 0.881 \\
\hline Glutaraldehyde/30 minutes & -0.026 & 0.056 & 0.994 \\
\hline $\begin{array}{l}\text { Povidone-iodine/30 } \\
\text { minutes }\end{array}$ & 0.026 & 0.056 & 0.993 \\
\hline NaOCl/5 minutes & 0.181 & 0.056 & 0.012 \\
\hline Glutaraldehyde/5 minutes & 0.025 & 0.056 & 0.994 \\
\hline Povidone-iodine/5 minutes & 0.090 & 0.056 & 0.412 \\
\hline
\end{tabular}

$\mathrm{NaOCl}=$ Sodium hypochlorite

Two-way ANOVA showed that over time, the surface roughness of the casts retrieved from silicone impressions disinfected by immersion decreased $(\mathrm{P}=0.002)$, but no significant difference was noted between the disinfectants $(\mathrm{P}=0.243)$. Also, the interaction effect of time and the type of disinfectants on the surface roughness was not significant $(\mathrm{P}=0.071)$.

\section{Discussion}

This study showed that an increased immersion time of impressions in disinfecting solutions caused changes in the roughness of the casts. Thus, the null hypothesis of the present study was rejected.

Bacterial contamination and transmission following contact with blood and saliva during dental procedures are inevitable. When the impressions are poured with dental stone, bacterial colonies are transferred to casts. Therefore, an efficient disinfection of impressions is necessary to prevent the transmission of infection from the clinic to the laboratory. On the other hand, disinfectants should not change the properties of impression materials as these changes will be transferred to the casts and cause inaccuracy in their physical properties. ${ }^{(13,16)}$

Several methods have been suggested to minimize microbial contamination such as the addition of disinfectants and water to the alginate powder, immersion of impressions in disinfectants, spraying the disinfecting agent on the impression, or mixing the gypsum with disinfectants to obtain disinfected casts. ${ }^{(16,17-20)}$

The spraying technique and immersion of impressions in disinfectants are more common techniques for disinfection of impressions. ${ }^{(12)}$ In the current study, three commonly used disinfectants available in the market were used $(1 \%$ $\mathrm{NaOCl}, 2.4 \%$ glutaraldehyde, and $5 \%$ povidoneiodine) for disinfection of impressions by immersion. The selection of these disinfecting solutions was due to their ability to eliminate HIV and HBV in 10 minutes. ${ }^{(21,22)}$ Also, disinfection of impressions by the immersion technique is more reliable and has been recommended by the American Dental Association (ADA). ${ }^{(21)}$ A digital roughness tester was used for measuring the specimens> surface roughness, which has a comparable precision to profilometer and has been used in previous studies. ${ }^{(23,24)}$

The surface roughness of type IV gypsum casts after 5 minutes of immersion in disinfectants showed that the disinfecting solutions were not significantly different, but $1 \% \mathrm{NaOCl}$ showed a significant difference with the control group such that the surface roughness of the casts immersed in $1 \% \mathrm{NaOCl}$ increased after 5 minutes. The surface roughness after 30 minutes of immersion in disinfectants showed no significant difference within the studied groups or with the control group, but a significant difference was noted between the samples immersed for 5 minutes and those immersed for 30 minutes. In other words, increasing the immersion time decreased the roughness of the casts. Also, it can be concluded that the type of disinfectants has no significant effect on surface roughness.

Several factors affect the roughness of gypsum casts, including the roughness of the impression material, the roughness of the tooth/ restoration, the size and dispersion of gypsum particles, and the inherent moisture of gypsum when exposed to different impression materials. ${ }^{(16,21)}$ Himanshu et al reported that absorption of additives by gypsum casts creates nuclei in the cast, which are subsequently crystalized and increase the strength of the cast. ${ }^{(22)}$ However, another study showed that organic acids and salts added to gypsum increase its setting time and decrease the strength. ${ }^{(23)}$ Such a controversy can be explained as follows: in the earlier 
study, additives did not react chemically with the impression material, while in the second study, chemical reactions occurred between the additives and gypsum, which result in the delayed setting of gypsum, jeopardizing the strength of the cast. When impressions are disinfected with different disinfectants, ions or molecules of the disinfectant penetrate into the surface of the impression material and are transferred to the resultant cast. In fact, they penetrate into gypsum and change its structure and its molecular orientation. (22) If the particles become closer due to this changing structure, the roughness and surface porosities of the cast would decrease. This explains the gradual reduction in the surface roughness of the specimens of the present study.

Abdelaziz et al stated that the addition of a disinfecting solution to water and mixing it with gypsum increases the surface porosity of casts. (16) Low wettability of dental stone mixed with a disinfecting solution could be a factor in increasing surface porosity. They suggested the addition of Arabic gum or calcium hydroxide to gypsum powder in order to decrease the size of crystals and subsequently the surface porosity and roughness. ${ }^{(16)}$ The results of the study by Abdelaziz et al was in agreement with those reported by Ivanovski et al and Kawamoto. ${ }^{(25,26)}$ They mixed different disinfecting solutions with gypsum and reported a reduction in the strength as well as an increase in the size of gypsum crystals and roughness. Also, a reduction in the compressive strength of type III and IV gypsum was noted. Their different methodology probably explains the difference in the results. ${ }^{(16)}$

The result of the study by Abass ${ }^{(27)}$ in which gypsum casts were disinfected with $\mathrm{NaOCl}$ was in line with those found by Abdelaziz et al. ${ }^{(16)} \mathrm{In}$ a recent study, calcium hypochlorite $(\mathrm{Ca}(\mathrm{ClO}) 2)$ caused changes in the size and shape of calcium sulfate dihydrate crystals in gypsum and increased the porosity of casts. The type of the disinfectant and their methodology explain the difference in the results. ${ }^{(27)}$

In the current study, one reason for decreasing the surface roughness is that over time, the polymerization of polymeric chains in the impression material would be more completed, and also, the free terminals of short chains would start the reaction. This phenomenon will result in a re- duced surface roughness in the impression material and subsequently in gypsum cast. In addition, it is likely that disinfectants that are in close proximity to impression materials increase the wettability of the impression material; this wettability might reduce the porosity of gypsum casts.

Overall, it may be stated that silicon impression materials, including condensation and addition types, have a better surface integrity than other materials. They have a hydrophobic nature, and their surfaces have a high resistance to hydrophilic disinfectants, irrespective of their type or duration of contact. ${ }^{(19,27)}$

\section{Conclusion}

Within the limitations of this study, the results showed that the type of the disinfectant had no significant effect on the surface roughness of gypsum casts retrieved from silicone impressions disinfected by immersion although an increased duration of disinfection affected the casts and decreased their surface roughness. It is recommended to evaluate other properties of final casts such as dimensional stability, surface details, and hardness in future studies to reach a better conclusion on the effect of disinfectants.

\section{Acknowledgements}

We are thankful to those who helped us with this article including the research center of the Dental Branch of Islamic Azad University, Tehran, Iran.

\section{References}

1. Johnson GH, Chellis KD, Gordon GE, Lepe X. Dimensional stability and detail reproduction of irreversible hydrocolloid and elastomeric impressions disinfected by immersion. J Prosthet Dent. 1998 Apr;79(4):446-53.

2. Kess RS, Combe EC, Sparks BS. Effect of surface treatments on the wettability of vinyl polysiloxane impression materials. J Prosthet Dent. $2000 \mathrm{Jul} ; 84(1): 98-102$.

3. Jagger DC, Al Jabra O, Harrison A, Vowles RW, McNally L. The effect of a range of disinfectants on the dimensional accuracy of some impression materials. Eur J Prosthodont Restor Dent. 2004 Dec;12(4):154-60.

4. Sinavarat P, Visayrath S. Effects of disinfection procedures on surface quality of compound impressions and the resultant gypsum casts. M 
Dent J. 2014 Sep;34(1):19-27.

5. Beyerle MP, Hensley DM, Bradley DV Jr, Schwartz RS, Hilton TJ. Immersion disinfection of irreversible hydrocolloid impressions with sodium hypochlorite. Part I: Microbiology. Int J Prosthodont. 1994 May-Jun;7(3):234-8.

6. Rodriguez JM, Curtis RV, Bartlett DW. Surface roughness of impression materials and dental stones scanned by non-contacting laser profilometry. Dent Mater. 2009 Apr;25(4):500-5.

7. Ho DD, Byington RE, Schooley RT, Flynn T, Rota TR, Hirsch MS. Infrequency of isolation of HTLV-III virus from saliva in AIDS. N Engl J Med. 1985 Dec 19;313(25):1606.

8. Herrera SP, Merchant VA. Dimensional stability of dental impressions after immersion disinfection. J Am Dent Assoc. 1986 Sep;113(3):419-22.

9. Moslehifard E, Lotfipour F, Robati Anaraki M, Shafee E, Tamjid-Shabestari S, Ghaffari T. Efficacy of Disinfection of Dental Stone Casts: Virkon versus Sodium Hypochlorite. J Dent (Tehran). 2015 Mar;12(3):206-15.

10. Malaviya N, Shrestha A. Comparative Evaluation of Surface Detail Changes and Compressive Strength of Gypsum Casts and Dies After Immersion in Hypochlorite Solution and Microwave Irradiation - An in Vitro Study. IJCMR. 2016;3(6):1547-51.

11. Stern MA, Johnson GH, Toolson LB. An evaluation of dental stones after repeated exposure to spray disinfectants. Part I: Abrasion and compressive strength. J Prosthet Dent. 1991 May;65(5):713-8.

12. Lepe X, Johnson GH. Accuracy of polyether and addition silicone after long-term immersion disinfection. J Prosthet Dent. 1997 Sep;78(3):2459.

13. Demajo JK, Cassar V, Farrugia C, Millan-Sango D, Sammut C, Valdramidis V, et al. Effectiveness of Disinfectants on Antimicrobial and Physical Properties of Dental Impression Materials. Int J Prosthodont. 2016 Jan-Feb;29(1):63-7.

14. Roy SM, Sridevi J, Kalavathy N. An evaluation of the mechanical properties of Type III and Type IV gypsum mixed with two disinfectant solutions. Indian J Dent Res. 2010 Jul-Sep;21(3):374-9. 15. Amin WM, Al-Ali MH, Al Tarawneh SK, Taha ST, Saleh MW, Ereifij N. The effects of disinfectants on dimensional accuracy and surface quality of impression materials and gypsum casts. J Clin
Med Res. 2009 Jun;1(2):81-9.

16. Abdelaziz KM, Combe EC, Hodges JS. The effect of disinfectants on the properties of dental gypsum: 1. Mechanical properties. J Prosthodont. 2002 Sep;11(3):161-7.

17. Kalantari MH, Malekzadeh A, Emami A. The effect of disinfection with sodium hypochlorite $0.5 \%$ on dimensional stability of condensation silicone impression materials of speedex and irasil. J Dent (Shiraz). 2014 Sep;15(3):98-103.

18. Ahila SC, Subramaniam E. Comparative evaluation of dimensional stability and surface quality of gypsum casts retrieved from disinfected addition silicone impressions at various time intervals: An in vitro study. J Dent Oral Hyg. 2012 Dec;4(4):34-43.

19. Ahila SC, Thulasingam C. Effect of disinfection on gypsum casts retrieved from addition and condensation silicone impressions disinfected by immersion and spray methods. SRM J Res Dent Sci. 2014 Aug;5(3):163-169.

20. Kotha SB, Ramakrishnaiah R, Devang Divakar D, Celur SL, Qasim S, Matinlinna JP. Effect of disinfection and sterilization on the tensile strength, surface roughness, and wettability of elastomers. J Investig Clin Dent. 2017 Nov;8(4).

21.Nishikiori R, Sawajiri M, Okuda T, Otoshi A, Watanabe K, Hirata I, et al. Effect of ozonated water on the surface roughness of dental stone casts. Dent Mater J. 2018 May;31:1-5.

22. Himanshu A, Anubha A, Varun K, Jyotsna S. Study of the effect of disinfectant solutions on the Physical properties of dental impressions. Indian J Dent Sci. 2014 Sep;3(6):1-6.

23. da Rosa GM, da Silva LM, de Menezes M, do Vale HF, Regalado DF, Pontes DG. Effect of whitening dentifrices on the surface roughness of a nanohybrid composite resin. Eur J Dent. 2016 AprJun;10(2):170-5.

24. Labašová E. Measurement of changes of the surface roughness in sliding area. Am Int J Contemp Res. 2013 Apr;3(4):1-5.

25. Ivanovski S, Savage NW, Brockhurst PJ, Bird PS. Disinfection of dental stone casts: antimicrobial effects and physical property alterations. Dent Mater. 1995 Jan;11(1):19-23.

26. Kawamoto A. Effects of mixing disinfectant solutions on properties of stone models [abstract]. J Nihon U. 1995;37:128-29.

27. Abass SM. The Effect of Disinfectant on the Microstructure of Dental Stone at Different Time Intervals. MDJ. 2007;4(2):199-205. 